\title{
Endemic and emerging arboviral diseases of livestock in Nigeria: a review
}

\author{
Daniel Oluwayelu ${ }^{1,2^{*}}$ (D) Adebowale Adebiyi ${ }^{1}$ and Oyewale Tomori ${ }^{3}$
}

\begin{abstract}
Arthropod-borne viruses (arboviruses) are the largest biologic group of vertebrate viruses and constitute important emerging infectious disease agents globally. Arthropod transmission provides a way for viruses to cross species barriers since the same arthropod may bite animals that rarely or never come into close contact in nature. In Nigeria, arboviruses have, over several decades, caused severe diseases in livestock resulting in great economic losses and, sometimes, infection of humans leading to morbidity and mortality. In the present review, a computerized search of existing literature was conducted using the Google search engine and PubMed electronic database to identify and review relevant publications on arboviral diseases of livestock in Nigeria. The keywords used were 'arbovirus', 'arthropod-borne viral diseases' or 'livestock diseases' and 'Nigeria' while the Boolean operator 'OR' was used to combine and narrow the searches. Additional information was obtained by searching the veterinary libraries for journals not listed in the database. The available publications were thereafter reviewed and findings qualitatively described. Our findings revealed that although there were several studies on arboviruses and the livestock diseases they cause in Nigeria, most of such reports were made four to six decades ago, with only a few reported recently. Consequently, the true economic and public health impact of these diseases are likely to be underestimated, mainly due to under-reporting or lack of awareness of them. Thus, it is essential to update information on arboviral diseases in Nigeria in order to increase awareness of the diseases and facilitate their prompt identification and reporting. The importance of routine surveillance for arbovirus livestock diseases and sentinel herd monitoring as basis for development of an early warning and alert system to prevent future outbreaks is discussed.
\end{abstract}

Keywords: Arboviruses, Livestock, Endemic, Emerging, Nigeria

\section{Background}

Arthropod-borne viruses (arboviruses) represent a considerable threat to human and animal health worldwide as several of them are found in different parts of the world, including Africa. More than five hundred arboviruses are known, of which about fifty cause diseases in domestic animals and many of the same cause zoonotic diseases [1]. Arboviruses pathogenic for animals belong to seven virus families: Togaviridae, Flaviviridae, Bunyaviridae, Reoviridae, Rhabdoviridae, Orthomyxoviridae and Asfarviridae (Table 1). They are transmitted to animals by five groups of hematophagous arthropods of the sub-phylum Chelicerata (Order Acarina, families Ixodidae and Argasidae - ticks) or

\footnotetext{
*Correspondence: ogloryus@yahoo.com

'Department of Veterinary Microbiology, University of Ibadan, Ibadan, Oyo State, Nigeria

${ }^{2}$ Centre for Control and Prevention of Zoonoses, University of Ibadan, Ibadan, Oyo State, Nigeria

Full list of author information is available at the end of the article
}

members of the class Insecta: mosquitoes (family Culicidae), biting midges (family Ceratopogonidae), sand flies (subfamily Phlebotominae) and cimicid bugs (family Cimicidae) [1].

Arboviruses have been isolated from vertebrates (man, domestic and wild animals) as well as from invertebrates (arthropods) [2, 3]. The arthropod vector acquires virus by feeding on the blood of viraemic animals; the ingested virus replicates in the tissues of the arthropod and can then be transmitted by bite to susceptible vertebrates [4]. Consequently, arthropod transmission provides a way for these viruses to cross species barriers, since the same arthropod may bite birds, reptiles and mammals that rarely or never come into close contact in nature [5]. Most arboviruses have restricted natural habitats in which specific receptive arthropod and vertebrate hosts are involved in the viral life-cycle. Vertebrate reservoir hosts are usually wild mammals, birds and/or domestic animals. The domestic animal species are, in most cases, infected incidentally for instance,

(c) The Author(s). 2018 Open Access This article is distributed under the terms of the Creative Commons Attribution 4.0 International License (http://creativecommons.org/licenses/by/4.0/), which permits unrestricted use, distribution, and 
Table 1 Arboviruses pathogenic for domestic and wild mammals

\begin{tabular}{|c|c|c|}
\hline Family & Species & Vector \\
\hline Togaviridae & $\begin{array}{l}\text { Eastern, Western and Venezuelan equine } \\
\text { encephalitis viruses, Sindbis, Middelburg, } \\
\text { Getah and Semliki Forest viruses }\end{array}$ & Mosquitoes (family Culicidae) \\
\hline \multirow[t]{2}{*}{ Flaviviridae } & $\begin{array}{l}\text { Yellow fever, Japanese encephalitis, Murray } \\
\text { Valley encephalitis, West Nile, Usutu, Israel } \\
\text { turkey meningoencephalitis, Tembusu and } \\
\text { Wesselsbron viruses }\end{array}$ & Mosquitoes (family Culicidae) \\
\hline & $\begin{array}{l}\text { Tick-borne encephalitis, louping ill, Omsk } \\
\text { hemorrhagic fever, Kyasanur Forest disease } \\
\text { and Tyuleniy viruses }\end{array}$ & Ticks (family Ixodidae) \\
\hline \multirow[t]{3}{*}{ Bunyaviridae } & $\begin{array}{l}\text { Rift Valley fever, La Crosse, Snowshoe hare } \\
\text { and Cache Valley viruses }\end{array}$ & Mosquitoes (family Culicidae) \\
\hline & $\begin{array}{l}\text { Nairobi sheep disease, Soldado and Bhanja } \\
\text { viruses }\end{array}$ & Ticks (family Ixodidae/Argasidae) \\
\hline & $\begin{array}{l}\text { Main Drain, Akabane, Aino, Shuni and } \\
\text { Schmallenberg viruses }\end{array}$ & Biting midges (family Ceratopogonidae) \\
\hline Reoviridae & $\begin{array}{l}\text { African horse sickness, Kasba, bluetongue, } \\
\text { epizootic hemorrhagic disease of deer, } \\
\text { Ibaraki, equine encephalosis, Peruvian } \\
\text { horse sickness and Yunnan virus }\end{array}$ & Biting midges (family Ceratopogonidae) \\
\hline Rhabdoviridae & $\begin{array}{l}\text { Bovine ephemeral fever, vesicular } \\
\text { stomatitis-Indiana, vesicular stomatitis-New } \\
\text { Jersey, vesicular stomatitis-Alagoas, and } \\
\text { Cocal viruses }\end{array}$ & $\begin{array}{l}\text { Sand flies (subfamily Phlebotominae)/ } \\
\text { mosquito }\end{array}$ \\
\hline Orthomyxoviridae & Thogoto virus & Ticks (family Ixodidae) \\
\hline Asfarviridae & African swine fever virus & Ticks (family Argasidae) \\
\hline
\end{tabular}

by the geographical extension of a reservoir vertebrate host and/or a vector arthropod [6]. In addition, arboviruses that cause periodic epidemics have ecologically complex enzootic cycles which often involve arthropod and vertebrate hosts that are different from those involved in epidemic or epizootic cycles. Furthermore, these enzootic cycles are critical in dictating the magnitude of epidemics because they are poorly understood and inaccessible to effective control measures, thereby providing for the amplification of such viruses [5].

Several factors, including deforestation with development of new forest-farmland margins, primitive irrigation systems which pay little or no attention to arthropod control, and uncontrolled urbanization with vector populations breeding in accumulations of water and sewage, have been implicated in the intrusion of humans and domestic animals into new arthropod habitats [6, 7]. In addition, new routing of long-distance bird migrations brought about by new man-made water impoundments and increased long-distance livestock transportation, with potential for carriage of viruses and arthropods, cause exposure of domestic animals to new arthropods. These activities disturb the natural ecology and hence natural arbovirus life-cycles, and have been incriminated in the geographical spread or increased prevalence of diseases caused by these viruses [5].

In the last six decades, several arboviruses of livestock were reported in Nigeria, with some being detected in the 1950s to 1980s [8], but with no recent cases reported. On the contrary, some arboviruses of livestock were only recently reported for the first time in the country $[9,10]$. Consequently, many animal health professionals in the livestock industry including veterinarians and animal health technologists, as well as students, may not be aware of their existence. Therefore, to increase awareness of these zoonotic diseases among health workers, there is a need to present updated information about the arboviruses and the diseases they cause in livestock in Nigeria. In the present review, a computerized search of existing literature was conducted using the Google search engine and PubMed and AGORA electronic databases to identify and download relevant publications on arboviruses of livestock in Nigeria. Additional information was obtained by searching the veterinary libraries for journals not listed in the database. A total of eighty-five publications on arboviral diseases of livestock and/or zoonotic arboviral diseases were considered, while those that focused only on arboviral diseases in humans were rejected. The available publications were thereafter reviewed and findings qualitatively described.

\section{Endemic arboviruses of livestock in Nigeria}

During the last six decades, several arboviruses causing disease in livestock have been isolated or reported in Nigeria and some have acquired an endemic status in the animal population (Table 2). The recognition of arboviral diseases 
Table 2 Arboviruses of livestock isolated/reported in Nigeria 1950-2016

\begin{tabular}{|c|c|c|c|c|}
\hline Virus & First report (country) & $\begin{array}{l}\text { First isolation/ } \\
\text { report in Nigeria }\end{array}$ & Source & Reference \\
\hline Bluetongue & 1905 (South Africa) & 1974 & $\begin{array}{l}\text { Culicoides spp., } \\
\text { shrews (Crocidura spp.) }\end{array}$ & [22] \\
\hline Rift Valley fever virus & 1930 (Kenya) & 1959 & Sheep & {$[45]$} \\
\hline \multirow[t]{2}{*}{ West Nile fever virus } & 1937 (Uganda) & 1959 & Animals & [68] \\
\hline & & 1973 & Humans & [69] \\
\hline African horse sickness & 1900 (South Africa) & 1971 & Horse & [107] \\
\hline $\begin{array}{l}\text { Crimean-Congo haemorrhagic } \\
\text { fever virus }\end{array}$ & 1944-1945 (Crimea) & 1970 & $\begin{array}{l}\text { Cattle, goats, } \\
\text { hedgehogs, ticks }\end{array}$ & [133] \\
\hline African swine fever virus & 1910 (Kenya) & 2001 & Pigs & [144] \\
\hline Kotonkan & 1967 (Nigeria) & 1967 & Culicoides spp. & {$[150]$} \\
\hline Bovine ephemeral fever virus & 1907 (Rhodesia) & 1973 & Cattle & [159] \\
\hline Wesselsbron virus & 1955 (South Africa) & 1968 & Camel & [162] \\
\hline Schmallenberg virus & 2011 (Germany) & 2015 & Cattle & [9] \\
\hline Akabane virus & 1959 (Japan) & 2016 & Cattle, sheep & {$[10]$} \\
\hline
\end{tabular}

of veterinary importance in domestic animals and the isolation of their etiological agents can be attributed to factors such as establishment of virus laboratories, availability of trained veterinarians and allied professionals, improvement in disease surveillance strategies as well as use of modern, more rapid and more sensitive diagnostic techniques and equipment.

\section{Bluetongue virus}

Bluetongue (BT) is an infectious, non-contagious arthropod-borne viral disease of ruminants which was first described in an outbreak in sheep in South Africa [11]. It is caused by the BT virus (BTV) which is almost exclusively transmitted by arthropods of the Culicoides spp. and is the prototype species of the genus Orbivirus, family Reoviridae [12]. BTV is notifiable to the World Organisation for Animal Health (OIE), as trade and movement restrictions that may cause severe economic losses for affected regions are commonly implicated in outbreaks. Currently, 27 BTV serotypes are recognized worldwide; the 27th serotype (BTV-27) is a novel virus recently discovered in asymptomatic goats in Corsica, France [13]. This serotype exists so far as three different variants, namely v01-v03 [14]. Other variants of the virus include BTV-XJ1407 and BTV-X ITL2015 detected in goats from China [15] and Sardinia, Italy [16], respectively. Further, two putative novel serotypes, BTV-28 and BTV-29 that were detected in a Capripox vaccine in the Middle East and in an alpaca in South Africa, respectively, have recently been suggested [13, 17]. The clinical signs of BT are often severe in infected sheep while in cattle, goats and camelids, BT infection is usually asymptomatic, although some clinical cases were observed in cattle during the BTV-8 outbreak that occurred in North Europe (reviewed in [14]).

Since the first report of BT in Nigeria in 1943 [18], the disease has become widespread among domestic ruminants in the country with epizootics reported at different times [19-21]. According to Fagbami \& Ojeh [8], indigenous breeds of sheep seem to be relatively resistant as outbreaks of the disease that have occurred principally involved exotic breeds of sheep. Lee et al. [22], during routine virus surveillance, successfully isolated BT viruses from Culicoides spp. (serotypes 4, 6, 10 and 16) and shrews (Crocidura spp.) (serotype 7). In addition, at least 14 BTV serotypes have been reported to exist in Nigeria [23], with no cross-immunity between the various serotypes. Also, studies in the last four decades [24-30] have revealed the presence of moderate to high levels of BTV-specific antibodies in sheep, goats and cattle from southern and northern Nigeria, an indication that the disease is enzootic in the country. Several species of Culicoides that feed on domestic ruminants, such as Culicoides imicola and C. milnei, which have been incriminated as biological vectors of BT elsewhere, occur in large numbers in Nigeria [31, 32]. This may account for the widespread nature of the disease in the country.

\section{Rift Valley fever virus}

Rift Valley fever (RVF) is a zoonotic, arthropod-borne viral disease important in domesticated ruminants [33]. This disease is characterized by high mortality rates in young animals and abortions in pregnant ruminants [33, 34]. Rift Valley fever can affect many species of animals including sheep, cattle, goats, buffalo, camels, monkeys as well as gray squirrels and other rodents [34, 35]. It is caused by the RVF virus (RVFV), an RNA virus in the genus 
Phlebovirus, family Bunyaviridae [36], that is primarily transmitted by mosquitoes of the Aedes and Culex spp. The virus appears to survive in the dried eggs of Aedes mosquitoes and epidemics are associated with hatching of the eggs during years of heavy rainfall and localized flooding [33, 37]. The primary amplifying hosts are sheep and cattle. Once it has been amplified in animals, RVFV can also be transmitted by other vectors, including many mosquito species and possibly other biting insects such as ticks and midges. In addition, animal products such as fresh, chilled and frozen meat, milk and milk products, wool, bones, skin and hides have been speculated to be potential sources of the virus [38]. The virus can also be transmitted in utero to the fetus [37].

RVF was first reported during an epizootic of the disease in sheep in Kenya [39], and since then there have been several reports of outbreaks elsewhere in Africa [40-44]. The virus was first isolated in Nigeria from the tissues of imported Merino sheep that died of the disease [45]. In 1970, Lee isolated three strains of the virus from Culicoides spp. and Culex antennatus mosquitoes collected at the University of Ibadan farm (Annual Report, Virus Research Laboratory, Ibadan 1970; reviewed in [8]). Subsequently, studies have shown serological evidence of RVFV in sheep, cattle, goats, horses and camels [46-49]. It is not yet clear whether the indigenous breeds of sheep are susceptible to overt Rift Valley fever. Experimental transmission studies revealed that although the West African dwarf (WAD) sheep developed high fever and exhibited viraemia, they were not susceptible to fatal illness [50]. However, Tomori [51] reported death and abortion in adult WAD ewes experimentally inoculated with the Nigerian indigenous virus strain.

Rift Valley fever virus has been recognized in Nigeria for about six decades; nevertheless, the present knowledge of the epizootiology suggests that the virus does not constitute a serious threat to the livestock industry in the country. According to Fagbami \& Ojeh [8], the Nigerian strains of the virus may be apathogenic to the local breeds of sheep and may differ antigenically from the more virulent strains isolated elsewhere. Moreover, serological investigations [52] revealed that the indigenous isolates of RVFV are similar to the neurotropic Smithburn strain obtained from Uganda, which has also not been associated with severe animal disease in that country.

\section{West Nile virus}

West Nile virus (WNV) is a zoonotic, mosquito-borne pathogen that belongs to the Japanese encephalitis virus serocomplex within the genus Flavivirus, family Flaviviridae [53]. It was first isolated in 1937 from the blood of a woman in the West Nile province of Uganda who had a mild febrile illness [54]. Since then it has been associated with sporadic and major outbreaks in humans and horses, as frequent outbreaks with increased proportion of neurological disease cases have been reported $[55,56]$. The virus is maintained in an enzootic cycle between ornithophilic mosquitoes and birds by infected Culex spp. mosquitoes. Consequently, a number of wild birds are the main reservoir hosts in enzootic areas. Infected birds develop transient viraemia that allows transmission of the virus to feeding female mosquitoes [57]. WNV is associated with high morbidity and mortality in birds, horses and humans $[58,59]$, thereby constituting a major veterinary and public health concern. Following bites from WNV-infected female mosquitoes, infection is often unapparent or mild in humans but may produce severe and even fatal encephalitis in horses [57, 60, 61].

West Nile virus has a worldwide distribution throughout Africa, the Middle East, Asia, southern Europe, Australia and North America [57, 62]. Two distinct lineages of the virus have been revealed by phylogenetic analysis of the genomes of a number of strains; lineage 1 viruses have been isolated from the north eastern United States, Europe, Israel, Africa, India and Russia while lineage 2 viruses, which have previously been isolated only in sub-Saharan Africa and Madagascar [63], are now endemic also in Europe and have been reported in humans, birds and mosquitoes [64-67].

In Nigeria, despite numerous isolations of WNV from the animal population and the demonstration of WNV-specific antibodies in human sera [68], the virus was not isolated from humans until 1973 when Tomori and co-workers successfully recovered it from the blood and serum of three febrile children in Ibadan [69]. During the last three decades, there have been reports of detection of WNV antibodies in domestic animals and humans in Nigeria [70-75]. In addition, viral RNA was detected by reverse transcriptase-polymerase chain reaction in humans and mosquitoes [74], while reports of co-infection of WNV in malaria and typhoid fever patients [76] as well as in cases of undifferentiated febrile illness [77] have also been made. These reports underscore the need for consideration of West Nile fever in the differential diagnosis of febrile illnesses in Nigeria since its clinical presentation could be mistaken for malaria and typhoid fevers, which are endemic in the country.

\section{Usutu virus}

Originally isolated in South Africa in 1959 from Culex neavei mosquitoes [78], Usutu virus (USUV) is a mosquito-borne flavivirus belonging to the Japanese encephalitis virus serocomplex [79]. It is regarded as a neglected emerging arbovirus in Europe and Africa [80], and has been detected in mosquitoes, animals and humans in countries of both continents [81-89]. The natural life-cycle of USUV involves mosquito-bird-mosquito cycles, 
in which ornithophilic mosquitoes (mainly Culex spp.) act as vectors and birds (mainly wild birds) as amplifying hosts. It has been demonstrated that multiple mosquito and avian species are involved in perpetuating the USUV life-cycle [90, 91]. In addition to C. neavei, USUV has also been isolated from other Culex species including C. quinquefasciatus, an anthropophilic vector that was directly implicated in the emergence of the virus in Europe, and from Aedes mosquitoes (reviewed in [92]). Generally, mosquitoes facilitate viral transmission to humans, horses, dogs, wild boars and rodents which may act as incidental hosts $[83,85,88]$. The isolation of USUV from bats in Germany was recently reported [87].

Since its first discovery in Africa, USUV had typically been isolated from mosquitoes and had never been associated with serious illness in mammals [79]. The virus had been isolated from human sera in Africa only on two occasions: from a man with fever and skin rash in Central African Republic in 1981 and from a 10-year-old child with fever and jaundice in Burkina Faso in 2004 [84]. In Nigeria, apart from the first report of USUV made over four decades ago during a serological investigation to determine antigenic relationships among eight Nigerian WNV isolates [81], there is scarcity of information on USUV infection. These authors showed that one of the WNV isolates was actually a strain of USUV. Conversely, in the last two decades, USUV has been demonstrated to be responsible for several outbreaks of overt disease in birds in Europe. Specifically, severe neurologic symptoms, often fatal, in wild and domestic birds were observed [93, 94]. Likewise, cases of severe encephalitis and USUV neuroinvasive infections of humans have been reported in different European countries $[89,95,96]$.

Considering that USUV is an emerging WNV-related flavivirus which causes, in endemic areas, severe disease in humans, there is a need to confront the menace of USUV and WNV with similar preventive measures while adopting the One Health approach for investigation of human cases that involve animals and insects [89].

\section{African horse sickness virus}

African horse sickness virus (AHSV) is a double-stranded RNA virus belonging to the genus Orbivirus of the family Reoviridae. It causes African horse sickness (AHS), an acute or sub-acute infectious, non-contagious viral disease of equids (horses, mules, donkeys and zebras) characterized by fever, cardiac and pulmonary manifestations, and high mortality in susceptible animals. The virus exists as nine immunologically distinct serotypes, all of which have been identified and considered enzootic in sub-Saharan Africa $[97,98]$. Although the zebra is considered the natural host and main reservoir of AHSV in Africa, other equine species and their crossbreeds are susceptible to infection and, with the exception of donkeys, usually show clinical disease and high mortality [99]. Owing to the potential of this virus to cause widespread death and debilitating disease in naive equid populations, it is listed as a notifiable equine disease by the World Organization for Animal Health (OIE), which makes outbreaks of the disease compulsorily notifiable [100]. Transmission of AHSV occurs almost entirely through hematophagous arthropods, which act as biological vectors. Field and laboratory-based studies have implicated Culicoides biting midges (Diptera: Ceratopogonidae) as the primary vectors of AHSV. By far the most important species in the field transmission of the virus is C. imicola [101, 102], although mosquitoes such as Anopheles stephensi and Aedes aegypti, the camel tick (Hyalomma dromedarii), the brown dog tick (Rhipicephalus sanguineus) and biting flies such as Stomoxys calcitrans have also been shown to be possible vectors (reviewed in [102]).

AHS was first described in West Africa during the mid-nineteenth century, and by the turn of the twentieth century its cyclical appearance every 5-6 years was anecdotally correlated with extensions of the rainy season [102]. According to Parker et al. [103], AHSV activity often peaks during the latter part of the rainy season due to the increase in Culicoides vector population during that period. In Nigeria, cases of AHS were described and diagnosed clinically and by serological tests in the northern parts of the country between 1931 and 1967 [104-106]. However, since the first documented outbreak and subsequent isolation of the virus from a dead horse in Nigeria in 1970 [107], sporadic outbreaks of AHS have occurred in different regions of the country [108-111]. However, unlike previous outbreaks in which AHSV serotype 9 was implicated, Fasina et al. [112] reported the first isolation of a serotype $2 \mathrm{AHSV}$ in the northern hemisphere from an outbreak in Lagos in 2007. Furthermore, Lazarus et al. [113] reported the detection of AHSV by real-time reverse transcription-polymerase chain reaction in tissue samples of a captive zebra that died in a game reserve in Bauchi, Nigeria. In addition, serologic studies in domestic animals have revealed the existence of AHSV antibodies (serotypes 4 and 9) in horses, donkeys, camels and dogs in Nigeria $[110,114-116]$.

\section{Crimean-Congo haemorrhagic fever virus}

Crimean-Congo haemorrhagic fever (CCHF) is a fatal zoonotic tick-borne viral infection endemic in many countries in Africa, Asia, Europe and the Middle East $[117,118]$. The CCHF virus (CCHFV) is an RNA virus belonging to the Nairovirus genus of the family Bunyaviridae, and is primarily transmitted by Hyalomma ticks, particularly $H$. marginatum, although more than 30 tick species have been shown to be capable of transmitting the virus between vertebrate hosts $[119,120]$. The 
geographical range of this virus is the most extensive of the medically significant tick-borne viruses important to human health [121]. Human infection occurs through bites of or crushing infected ticks on bare skin with an open wound [122], by direct contact with animal blood or tissues [123], and by drinking unpasteurized milk from infected animals. Aerosol transmission and possible horizontal transmission from mother to child have also been reported [121, 124]. The majority of CCHF cases have occurred in people involved in the livestock industry, such as agricultural and slaughterhouse workers and veterinarians [125]. However, this virus causes unapparent infection or mild fever in cattle, sheep and goats with viraemia of sufficient intensity to infect adult ticks [126]. Nonetheless, infected livestock, particularly cattle, could provide virus for tick-borne transmission to highly susceptible humans and therefore play an important role in the epidemiology of the disease [127].

In West Africa, studies have revealed the presence of CCHFV in Niger [128], Mauritania [129], Senegal [130], Burkina Faso [131] and Mali [132]. However, apart from earlier reports of CCHFV made over three decades ago in domestic animals, wildlife, ticks and humans in Nigeria [133-136], and the recent reports of serological and virological evidence of the virus in humans in Borno State [49, 137], there is paucity of information on CCHFV and its impact in Nigeria, especially in domestic animals.

\section{African swine fever virus}

African swine fever (ASF) is a highly infectious and contagious disease of domestic pigs caused by the African swine fever virus (ASFV) [138], which belongs to the genus Asfivirus in the family Asfarviridae [139]. The disease occurs in both domestic and wild pigs throughout sub-Saharan Africa and is transmitted through the bite of soft ticks (Ornithodoros moubata). Maintenance and transmission of ASFV involves the cycling of virus between these ticks and the free-living population of warthogs and bush pigs [140]. Mortality due to ASF can be as high as $100 \%$ in a naive population resulting in severe economic losses and socio-economic impact on production, trade and food security. Whereas ASF is currently considered enzootic in eastern and southern Africa, and the epidemiologic cycles of importance in many of the countries in these regions are well understood [141], little is known about the epidemiology of the infection in West Africa despite evidence of considerable spread of disease in this region in the late 1990s [142].

The first confirmed outbreak of ASF in Nigeria was reported in Lagos and Ogun States in September 1997. Between September 1997 and July 1998, other outbreaks of the disease were reported from the same states, and it was speculated that the virus was introduced through pigs from the Republic of Benin [143]. The isolation and molecular characterization of the ASFV strain involved in the outbreak was reported by Odemuyiwa et al. [144]. Subsequently, sporadic outbreaks have occurred in Nigeria with devastating impacts on subsistence and commercial piggery activities [140, 145-148]. In addition, Luther et al. [149] reported detection of viral DNA in a Nigerian bush pig (Potamochoerus porcus) for the first time, thus establishing a role for wild pigs in the epidemiology of the disease in Nigeria.

\section{Kotonkan virus}

Kotonkan virus (KOTV) is a rhabdovirus first isolated in Nigeria from Culicoides spp. collected at the University of Ibadan Agricultural Farm in December 1967 and found to be antigenically related to Mokola virus, a member of the rabies serogroup [150]. The first association of this virus with animal disease was reported when an exotic breed of cattle imported into Nigeria came down with a debilitating illness characterized by fever, lameness, muscle soreness, anorexia, weight loss and recumbency [150]. Although natural clinical disease in the indigenous breed of cattle is rare, experimental studies using a mouse brain-adapted strain of the virus showed that it was pathogenic for White Fulani cattle [151]. It has been suggested that the rarity of natural overt disease in the indigenous breeds of cattle may be due to the fact that young calves get infected when they still have some level of protective maternal antibody [150]. Although Kotonkan virus is not frequently encountered, serological studies have revealed that it is active in the country with neutralizing antibodies demonstrated in man and several species of domestic and wild animals [150].

\section{Bovine ephemeral fever virus}

Bovine ephemeral fever virus (BEFV) is an arthropod-borne rhabdovirus which is classified as the type species of the genus Ephemerovirus. It causes an acute febrile illness of cattle and water buffalo known as bovine ephemeral fever (or three-day sickness, bovine enzootic fever, bovine influenza or stiffseitke) that is characterized by biphasic fever, salivation, oculo-nasal discharge, anorexia, recumbency, muscle stiffness, shifting lameness, and enlargement of peripheral lymph nodes [152]. A unique feature of the disease is its rapid onset and rapid recovery, lasting only 1-3 days, hence the name "three-day sickness". Although BEF has been recognized for many decades in Africa [153], it is presently enzootic and seasonally epizootic in Australia, Asia, Africa and the Middle East, usually not extending beyond a zone limited by the latitudes of $38^{\circ} \mathrm{N}$ to $36^{\circ} \mathrm{S}[154,155]$. The disease produces considerable economic impact due primarily to cessation of lactation in dairy cattle, loss of 
condition in beef cattle and the immobilisation of water buffalo used for draught power $[155,156]$. BEF also impacts on trade in live cattle from infected zones and there is evidence that the risks of inter-continental spread of BEFV through animal transport or vector translocation may be increasing [157]. BEFV has been isolated from various species of Culicoides including C. imicola, C. pallidipennis and C. brevitarsis, as well as from different mosquito species such as Anopheles, Culex, Aedes and Uranotaenia [reviewed in 152]. This rhabdovirus is also pathogenic for several laboratory hosts such as mice and cell culture [158]. The first virological evidence of BEF in Nigeria was in 1973, when two isolates of the virus were obtained from sick cattle on the University of Ibadan farm [159]. This was followed by the study of Tomori et al. [160], who demonstrated the presence of serum antibodies to the virus in calves. According to Kemp et al. [159], the disease has been known to herdsmen in Nigeria for many years, occurring regularly at the beginning of the wet season.

\section{Wesselsbron virus}

Wesselsbron virus (WSLV), a mosquito-borne flavivirus, is the aetiological agent of a severe disease of sheep characterized by high fever, severe leucopenia in adult sheep, abortion in pregnant ewes and high mortality in lambs. The virus was originally isolated during a severe epizootic in sheep in South Africa [161] but was first isolated in Nigeria from the blood of an apparently healthy camel in 1968 [162]. Since then, no report of clinical cases of Wesselsbron virus infection has been made in the country. However, experimental studies have revealed that the virus can produce overt clinical disease in West African dwarf sheep [163]. Since its first isolation by Kemp et al. [162], the virus has not been isolated again from animals in Nigeria. This has been partly attributed to the low level of virus surveillance in domestic animals. In addition, the range system of animal husbandry in Nigeria and the occurrence of several flaviviruses (such as Yellow fever, West Nile and Dengue) in the country predispose the local livestock to mixed or multiple flavivirus contacts resulting in the development of heterologous flavivirus antibodies in domestic animals which probably modify the virus activity [8]. Such immunity has been shown to reduce both the level of viraemia and severity of clinical disease in indigenous breeds [164]. However, the virus has been successfully isolated from humans [165], while antibodies against it have been demonstrated in animals $[71,166,167]$.

\section{Emerging arboviruses of livestock in Nigeria}

An emerging viral disease is one that is newly recognized or newly evolved, or that has occurred previously but shows an increase in incidence or expansion in geographical, host, or vector range [5]. In recent years, some diseases of livestock caused by arboviruses such as Schmallenberg virus and Akabane virus that have hitherto not been reported in Nigeria have been described. It is therefore important that field veterinarians, animal health workers and undergraduate students of Veterinary Medicine in the country be aware of their existence.

\section{Schmallenberg virus}

Schmallenberg virus (SBV) was first detected in November 2011 in a pool of blood samples from clinically affected dairy cows following reports of hyperthermia and drop in milk production in adult dairy cows in North-west Germany and The Netherlands [168]. The virus is a novel member of the family Bunyaviridae, genus Orthobunyavirus and is an enveloped, negative-sense, segmented, single-stranded RNA virus that is closely related to Shamonda virus, which belongs to the Simbu serogroup of viruses that includes Sango, Sabo and Shuni viruses $[169,170]$. Since the first cases from Germany and The Netherlands, this economically important disease in ruminants has caused a large epidemic with several reports of clinical and serologic evidence of the disease mostly from Europe [171-173]. SBV is associated with abortions, stillbirths, and congenital malformations in cattle, sheep and less often, goats [174] and has been shown to be neurotropic in lambs and calves infected in utero $[175,176]$. The virus is also able to infect wild cervids and llamas but no clinical signs or macroscopic abnormalities have been recorded for these species [177, 178].

Several studies have reported the presence of SBV in different species of Culicoides which has been identified as the main vector [179-182]. These studies suggest that Culicoides species identified as vectors for BTV also act as vectors for the transmission of SBV [183, 184]. In Africa, little information exists on SBV presence in the livestock population as clinical and serological evidence of the virus have been provided only in four countries including South Africa, Mozambique, Tanzania and Nigeria [9, 185-187]. In the Nigerian study [9], SBV antibodies were detected in $29.2 \%$ of exotic and indigenous cattle tested using a commercial indirect ELISA kit that detects antibodies against recombinant SBV nucleoprotein in ruminant sera. However, in order to preclude the possibility of cross-reactivity with other Simbu serogroup viruses some of which have previously been reported in Nigeria, a larger serosurvey was conducted with cattle and sheep sera from different vegetation zones of the country using both the ELISA and serum neutralisation tests (unpublished observations). The authors detected serum neutralizing antibodies against SBV, Shamonda 
and Simbu viruses in cattle and sheep sera across the three vegetation zones studied.

\begin{abstract}
Akabane virus
Akabane virus (AKAV) is named after the Japanese village where the virus was first isolated from mosquitoes (Aedes vexans and Culex tritaeniorhynchus) in 1959 [188]. The virus belongs to the genus Orthobunyavirus of the family Bunyaviridae, in the Simbu serogroup of viruses [189]. Akabane virus is a teratogenic, Culicoides-borne virus that replicates in many kinds of natural host species and in several experimental animals [190]. Based on serological evidence, cattle, horses, donkeys, sheep, goats, pigs, camels and buffaloes appear to be infected in natural situations [191, 192]. AKAV has been shown to be an important pathogen causing seasonal epizootics of reproductive disorders (abortions, premature births, and stillbirths) and congenital arthrogryposis, hydranencephaly or microencephaly in cattle, sheep and goats, sometimes resulting in significant economic losses [5, 193].

In Africa, limited information based on virus isolation and/or serology revealed the presence of AKAV in Kenya [191, 194], Sudan [195, 196], South Africa [197, 198], Zimbabwe [199], Tanzania [187] and Nigeria [10]. In Nigeria, although abortions and congenital malformations associated with AKAV such as arthrogryposis, kyphosis, and scoliosis have been reported in ruminants $[200,201]$, the virus has not received adequate attention as a possible cause of these conditions. However, the recent detection of antibody-positive animals among unvaccinated cattle and sheep [10] provides evidence of AKAV infection in Nigeria. The findings highlight the need for further virological, entomological and molecular investigations in order to determine the role of AKAV as aetiology of abortions and congenital malformations in ruminants in Nigeria.
\end{abstract}

\section{Conclusions}

Arthropod-borne viruses cause severe diseases of livestock resulting in great economic losses. Further, such infections often extend to the human population leading to morbidity and mortality with significant public health impact. In Nigeria, rapid urbanization coupled with the encroachment of individuals and their livestock into arthropod habitats has heightened the risks of animal to human transmission of viruses. However, despite these attendant risks and consequences of arboviral infections, the true economic and public health impact of these diseases are most likely underestimated, mainly due to under-reporting of disease events. Therefore, there is a need for increased awareness on the existence of these arboviral agents as well as continuous surveillance for them in order to facilitate their prompt identification and reporting to relevant government agencies. Routine serological, virological, entomological and molecular surveillance for these arboviral agents among livestock herds should be encouraged as their early detection would enable the deployment of pragmatic preventive measures to forestall their 'escape' into the human population. In addition, since the incidence of these diseases is generally higher during the rainy season due to increased vector activity, sentinel herd monitoring will yield useful data that can serve as the basis for an early warning and alert system to prevent future outbreaks.

\section{Abbreviations \\ AHSV: African horse sickness virus; AKAV: Akabane virus; ASFV: African swine fever virus; BEFV: Bovine ephemeral fever virus; BTV: Bluetongue virus; CCHFV: Crimean-Congo haemorrhagic fever virus; KOTV: Kotonkan virus; OIE: World Organisation for Animal Health; RVFV: Rift Valley fever virus; SBV: Schmallenberg virus; WAD: West African dwarf; WHO: World Health Organisation; WNV: West Nile virus; WSLV: Wesselsbron virus}

\section{Authors' contributions}

DO conceived the study and its design, participated in the database search for publications used and their analysis, and revised the different versions of the manuscript. AA was involved in database search and analysis of publications used, made the first draft and contributed to revisions of subsequent versions of the manuscript. OT participated in the study design, searched for relevant publications and revised different versions of the manuscript. All authors read and approved the final manuscript.

Ethics approval and consent to participate

Not applicable.

Competing interests

The authors declare that they have no competing interests.

\section{Publisher's Note}

Springer Nature remains neutral with regard to jurisdictional claims in published maps and institutional affiliations.

\section{Author details}

${ }^{1}$ Department of Veterinary Microbiology, University of Ibadan, Ibadan, Oyo State, Nigeria. ${ }^{2}$ Centre for Control and Prevention of Zoonoses, University of Ibadan, Ibadan, Oyo State, Nigeria. ${ }^{3}$ Nigerian Academy of Science, Academy House, University of Lagos Campus, 8A Ransome Kuti Road, Akoka, Yaba, Lagos State, Nigeria.

Received: 30 November 2017 Accepted: 22 May 2018

Published online: 07 June 2018

\section{References}

1. Hubalek Z, Rudolf I, Nowotny N. Arboviruses pathogenic for domestic and wild animals. Adv Virus Res. 2014;89:201-75.

2. Kuno G, Mackenzie JS, Junglen S, Hubálek Z, Plyusnin A, Gubler DJ. Vertebrate reservoirs of arboviruses: myth, synonym of amplifier, or reality? Viruses. 2017;9:185. https://doi.org/10.3390/v9070185.

3. Petersen LR, Busch MP. Transfusion-transmitted arboviruses. Vox Sanguinis. 2010;98:495-503.

4. World Health Organization (WHO). Arthropod-borne and rodent-borne viral diseases. Report of a WHO Scientific Group. World Hlth Org Tech Rep Series. 1985;719:1-116.

5. MacLachlan NJ, Dubovi EJ. Epidemiology and control of viral diseases. In: Maclachlan NJ, Dubovi EJ, editors. Fenner's veterinary virology. 4th ed. London: Academic Press; 2011. p. 125-48.

6. Gibbs EPJ. Virus diseases of food animals: world geography of epidemiology and control. London: Academic Press; 1981.

7. Satterthwaite D, McGranaham G, Tacoli C. Urbanization and its implications for food and farming. Philos Trans R Soc London B. 2010;365:2809-20.

8. Fagbami $\mathrm{AH}$, Ojeh C. Arthropod-borne viral infections of livestock in Nigeria. Trop Vet. 1983;1:61-9. 
9. Oluwayelu DO, Meseko CA, Adebiyi Al. Serological screening for Schmallenberg virus in exotic and indigenous cattle in Nigeria. Sok J Vet Sci. 2015;13:14-8.

10. Oluwayelu DO, Aiki-Raji CO, Umeh EC, Mustapha SO, Adebiyi Al. Serological investigation of Akabane virus infection in cattle and sheep in Nigeria. Adv Virol. 2016;2016:2936082.

11. Spreull J. Malarial catarrhal fever (Bluetongue) of sheep in South Africa. J Comp Path Therapeut. 1905;18:321-37.

12. Mertens PPC, Maan S, Samuel A, Attoui H. Genus Orbivirus. In: Fauquet CM, Mayo MA, Maniloff J, Desselberger U, Ball LA, editors. Virus Taxonomy: Eighth report of the International Committee on Taxonomy of Viruses. London: Elsevier/Academic Press; 2005. p. 466-83.

13. Zientara S, Sailleau C, Viarouge C, Höper D, Beer M, Jenckel M, et al. Novel bluetongue virus in goats, Corsica, France, 2014. Emerg Infect Dis. 2014;20: 2123-32.

14. Schulz C, Breard E, Sailleau C, Jenckel M, Viarouge C, Vitour D, et al. Bluetongue virus serotype 27: detection and characterization of two novel variants in Corsica, France. J Gen Virol. 2016;97:2073-83.

15. Sun EC, Huang LP, Xu QY, Wang HX, Xue XM, Lu P, et al. Emergence of a novel bluetongue virus serotype, China 2014. Transbound Emerg Dis. 2016; 63:585-9.

16. Savini G, Puggioni G, Meloni G, Marcacci M, Di Domenico M, Rocchigiani AM, et al. Novel putative bluetongue virus in healthy goats from Sardinia, Italy. Infect Gen Evol. 2017;51:108-17.

17. Wright IM. Serological and genetic characterisation of putative new serotypes of bluetongue virus and epizootic haemorrhagic disease virus isolated from an alpaca. MSc Thesis, North-West University, Potchefstroom, South Africa; 2014. p. 102.

18. Henderson WW. Veterinary Department, Nigeria. Annual report for the year 1943. Lagos: Government Press; 1945.

19. Howell PG. Bluetongue. In: Emerging diseases of animals. Italy: FAO Agricultural Series; 1968. p. 111-58.

20. Bida SA, Eid FIA. Bluetongue of sheep in Nigeria. J Nig Vet Med Assoc. 1974;3:12-6.

21. Bida SA, Njoku O, Eid FIA. Bluetongue in Wiltshire-horn sheep. Vet Rec. 1975; 97:496.

22. Lee VH, Causey OR, Moore DL. Bluetongue and related viruses in Ibadan, Nigeria. Isolation and preliminary identification of viruses. Am J Vet Res. 1974;35:1105-8.

23. Hernimann KAJ, Boorman JPT, Taylor WP. Bluetongue virus in a Nigerian dairy cattle herd. 1. Serological studies and correlation of virus activity to vector population. J Hyg Camb. 1983;90:177-93.

24. Moore DL, Kemp CE. Bluetongue and related viruses in Ibadan, Nigeria. Serological studies of domesticated and wild animals. Amer J Vet Res. 1974; 35:1115-20.

25. Taylor WP, McCausland A. Studies with bluetongue virus in Nigeria. Trop Anim Hlth Prod. 1976:8:169-73.

26. Durojaiye OA. Agar gel precipitin antibody to bluetongue virus in Nigerian cattle, sheep and goats. J Nig Vet Med Assoc. 1979;8:45-9.

27. Tomori O. Bluetongue and related viruses in Nigeria: Experimental infection of West African dwarf sheep with Nigeria strains of the viruses of epizootic hemorrhagic disease of deer (EHD) and bluetongue. Vet Micro. 1980:5:177-85.

28. Obi TU, Taylor WP, Ojo MO. Prevalence of bluetongue virus precipitating antibodies in sheep and goats in Southern Nigeria. Trop Vet. 1983:1:206-8.

29. Tomori O, Baba SS, Adu FD, Adeniji J. An overview and perspective on Orbivirus disease prevalence and occurrence of vectors in Africa. In: Walton D, Osborn A, editors. Bluetongue and related viruses. New York: CRC Press; 1992. p. 23-33.

30. Oluwayelu DO, Olatoye O, Akanbi M, Hoffmann B. Re-emergence of bluetongue virus infection in Oyo state, Nigeria. J Commonwealth Vet Assoc. 2011;27:234-8.

31. Dipeolu O. Potential vectors of bluetongue in Nigeria. Bull Anim Hlth Prod Afr. 1977:24:17-23

32. Dipeolu OO, Ogunrinade AF. Studies on Culicoides species of Nigeria. VII. The biology of some Nigerian Culicoides species. Z Parasitenkd. 1977;51:289-98.

33. Rift Valley fever. WHO factsheet. 2018. http://www.who.int/news-room/factsheets/detail/rift-valley-fever. Accessed 24 May 2018.

34. Center for Food Security and Public Health (CFSPH): Rift Valley fever. Infectious enzootic hepatitis of sheep and cattle. 2015. www.cfsph.iastate. edu/Factsheets/pdfs/rift_valley_fever.pdf. Accessed 24 May 2018.
35. Centers for Disease Control and Prevention (CDC): Rift Valley fever (RVF) 2016. https://www.cdc.gov/vhf/rvf/index.html. Accessed 24 May 2018.

36. Murphy FA, Fauquet CM, DHL B, Ghabrial SA, Jarvis A, Martelli GP, et al., editors. Virus taxonomy. Classification and nomenclature of viruses. Sixth report of the international committee on taxonomy of viruses. New York: Springer-Verlag; 1995.

37. Gerdes GH. Rift Valley fever. Rev Sci Tech Off Int Epiz. 2004;23:613-23.

38. World Health Organisation. Rift Valley fever: an emerging human and animal problem. WHO Offset Publication No. 63. Geneva: WHO; 1982. p. 69.

39. Daubney RJ, Hudson JR, Garnham PC. Enzootic hepatitis of Rift Valley fever: an undescribed virus disease of sheep, cattle and man from East Africa. J Pathol Bacteriol. 1931;34:543-79.

40. Meegan JM. The Rift Valley fever epizootic in Egypt: 1977-1978. I. Description of the epizootic and virological studies. Trans R Soc Trop Med Hyg. 1979;73:618-23.

41. Jouan A, Le Guenno B, Digoutte JP, Philippe B, Riou O, Adam F. A Rift Valley fever epidemic in Southern Mauritania. Ann Virol. 1988;139:307-8.

42. Zeller HG, Ba MM, Akakpo JA. Rift Valley fever epizootic in small ruminants in southern Mauritania (October 1993): risk of extensive outbreaks. Ann Soc Belg Med Trop. 1995;75:135-40.

43. Woods CW, Karpati AM, Grein T, McCarthy N, Gaturuku P, Muchiri E, et al. An outbreak of Rift Valley fever in North eastern Kenya, 1997-98. Emerg Infect Dis. 2002;8:138-44.

44. World Health Organization. Outbreaks of Rift Valley fever in Kenya, Somalia and United Republic of Tanzania, December 2006-April 2007. Wkly Epidemiol Rec. 2007;82:169-78.

45. Ferguson W. Identification of Rift Valley fever in Nigeria. Bull Epizoot Dis Afr. 1959:7:317-8.

46. Fagbami AH, Tomori O, Kemp GE. A survey of Nigerian domestic and wild animals for serum neutralizing antibody to the indigenous Rift Valley fever virus. Nig Vet J. 1973;2:45-8.

47. Ezeifeka GO, Umoh JU, Belin OED, Ezeokoli CD. A serological survey for Rift Valley fever antibody in Kaduna and Sokoto states of Nigeria. Int $J$ Zoonoses. 1985:9:147-51.

48. Olaleye OD, Tomori O, Schmitz H. Rift Valley fever in Nigeria: infections in domestic animals. Rev Sci Tech Off Int Epiz. 1996:15:937-46.

49. Bukbuk DN, Fukushi S, Tani H, Yoshikawa T, Taniguchi S, Iha K, et al. Development and validation of serological assays for viral haemorrhagic fevers and determination of the prevalence of Rift Valley fever in Borno state, Nigeria. Trans R Soc Trop Med Hyg. 2014;108:768-73.

50. Fagbami AH, Tomori O, Fabiyi A, Isoun TT. Experimental Rift Valley fever in West African dwarf sheep. Res Vet Sci. 1975;18:334-5.

51. Tomori O. Clinical, virological and serological response of the West African dwarf sheep to experimental infection with different strains of Rift Valley fever virus. Res Vet Sci. 1979:26:152-9.

52. Tomori O. Immunological reaction of Rift Valley fever virus strains from East and West Africa. Res Vet Sci. 1979:26:160-6.

53. Lindenbach BD, Thiel HJ, Rice CM. Flaviviridae: the viruses and their replication. In: Knipe DM, Howley PM, editors. Field's Virology. 5th ed. Philadelphia: Lippincott William; 2007. p. 1101-52.

54. Smithburn KC, Hughes TP, Burke AW, Paul JH. A neurotropic virus isolated from the blood of a native of Uganda. Amer J Trop Med Hyg. 1940;20:471-92.

55. Hubalek Z, Halouzka J. West Nile fever: a re-emerging mosquito-borne viral disease in Europe. Emerg Infect Dis. 1999;5:643-50.

56. Weiss D, Carr D, Kellachan J, Tan C, Phillips M, Bresnitz E, et al. Clinical findings of West Nile virus infection in hospitalized patients, New York and New Jersey, 2000. Emerg Infect Dis. 2001;7:654-8.

57. Campbell GL, Marfin AA, Lanciotti RS, Gubler DJ. West Nile virus. Lancet Infect Dis. 2002;2:519-29.

58. Triki H, Murri S, Le Guenno B, Bahri O, Hili K, Sidhom M, et al. West Nile viral meningoencephalitis in Tunisia. Med Trop. 2001;61:487-90.

59. Schuffenecker I, Peyrefitte CN, El Harrak M, Murri S, Leblond A, Zeller HG. West Nile virus in Morocco, 2003. Emerg Infect Dis. 2005;11:306-9.

60. Lim PY, Behr MJ, Chadwick CM, Shi PY, Bernard KA. Keratinocytes are cell targets of West Nile virus in vivo. J Virol. 2011;85:5197-201.

61. Qian F, Thakar J, Yuan X, Nolan M, Murray KO, Lee WT, et al. Immune markers associated with host susceptibility to infection with West Nile virus. Viral Immunol. 2014:27:39-47.

62. Roehrig JT, Layton M, Smith P, Campbell GL, Nasci R, Lanciotti RS. The emergence of West Nile virus in North America: ecology, epidemiology and surveillance. Curr Top Microbiol Imunol. 2002;267:223-40. 
63. Lanciotti RS, Ebel GD, Deubel V, Kerst AJ, Murri S, Meyer R, et al. Complete genome sequences and phylogenetic analysis of West Nile virus strains isolated from the United States, Europe, and the Middle East. Virology. 2002; 298:96-105.

64. Savini G, Puggioni G, Di Gennaro A, Di Francesco G, Rocchigiani AM, Polci $A$, et al. West Nile virus lineage 2 in Sardinian wild birds in 2012: a further threat to public health. Epidemiol Infect. 2013;141:2313-6.

65. Ravagnan S, Montarsi F, Cazzin S, Porcellato E, Russo F, Palei M, et al. First report outside eastern Europe of West Nile virus lineage 2 related to the Volgograd 2007 strain, north eastern Italy, 2014. Parasit Vectors. 2015;8:418.

66. Barzon L, Papa A, Lavezzo E, Franchn E, Pacenti M, Sinigaglia A, et al. Phylogenetic characterization of central/southern European lineage 2 West Nile virus: analysis of human outbreaks in Italy and Greece, 2013-2014. Clin Microbiol Infect. 2015;21:1122.e1-10.

67. Jungbauer CG, Hourfar MK, Stiasny K, Aberle S, Cadar D, Schmidt-Chanasit J, et al. West Nile virus lineage 2 infection in a blood donor from Vienna, Austria, August 2014. J Clin Virol. 2015;64:16-9.

68. McNamara FN, Horn DW, Porterfield JS. Yellow fever and other arthropodborne viruses; a consideration of two serological surveys made in SouthWestern Nigeria. Trans R Soc Trop Med Hyg. 1959;53:202-12.

69. Tomori O, Fagbami A, Fabiyi A. Isolations of West Nile virus from man in Nigeria. Trans R Soc Trop Med Hyg. 1978;72:103-4.

70. Ezeifeka GO, Sunday EO, Umoh JU. Surveillance for West Nile virus infection in domestic ruminants of Sokoto and Kaduna States of Nigeria. Zariya Vet. 1986:1:118-21.

71. Olaleye OD, Oladosu LA, Omilabu SA, Baba SS, Fagbami AH. Complement fixing antibodies against arboviruses in horses at Lagos, Nigeria. Rev Elev Med Vet Pays Trop. 1989;42:321-5.

72. Olaleye OD, Omilabu SA, Ilomechina EN, Fagbami AH. A survey for haemagglution-inhibiting antibody to West Nile virus in human and animal sera in Nigeria. Comp Immunol Microbiol Infect Dis. 1990;13:35-9.

73. Omilabu SA, Olaleye OD, Aina Y, Fagbami AH. West Nile complement-fixing antibodies in Nigerian domestic animals and humans. J Hyg Epidemiol Microbiol Immunol. 1990;34:357-63.

74. Baba MM, Saron MF, Diop O, Mathiot C, Adeniji JA, Olaleye OD. West Nile virus in mosquitoes and febrile patients in a semi-arid zone, Nigeria. J Amer Sci. 2006;2:28-34.

75. Sule WF, Oluwayelu DO, Adedokun RAM, McCracken F, Rufai N, Mansfield KL, et al. High seroprevalence of West Nile virus antibodies observed in horses from southwestern Nigeria. Vector Borne Zoonotic Dis. 2015;15:218-20.

76. Baba M, Logue $\mathrm{CH}$, Oderinde B, Abdulmaleek H, Williams J, Lewis J, et al. Evidence of arbovirus co-infection in suspected febrile malaria and typhoid patients in Nigeria. J Infect Dev Ctries. 2013;7:51-9.

77. Sule WF, Oluwayelu DO. Serologic evidence of exposure to West Nile virus among humans in Ibadan, southwestern Nigeria. Sudan J Med Sci. 2016;11:111-24.

78. Woodall JP. The viruses isolated from arthropods at the East African virus research institute in the 26 years ending December 1963. Proc E Afr Acad. 1964;2:141-6.

79. Ashraf U, Ye J, Ruan X, Wan S, Zhu B, Cao S. Usutu virus: an emerging flavivirus in Europe. Viruses. 2015;7:219-38.

80. Engel D, Jost H, Wink M, Borstler J, Bosch S, Gariglian MM, et al. Reconstruction of the evolutionary history and dispersal of Usutu virus, a neglected emerging arbovirus in Europe and Africa. MBio. 2016;7:e01938-15.

81. Odelola HA, Fabiyi A. Antigenic analysis of Nigerian strains of West Nile virus by neutralization test. Niger Med J. 1976;6:131-4.

82. Chevalier V, Reynaud P, Lefrancois T, Durand B, Baillon F, Balanca G, et al. Predicting West Nile virus seroprevalence in wild birds in Senegal. Vector Borne Zoon Dis. 2009;9:589-96.

83. Pecorari M, Longo G, Gennari W, Grottola A, Sabbatini A, Tagliazucchi S, et al. First human case of Usutu virus neuroinvasive infection, Italy, AugustSeptember, 2009. Euro Surveill. 2009;14:e19446.

84. Nikolay B, Diallo M, Boye CS, Sall AA. Usutu virus in Africa. Vector Borne Zoon Dis. 2011;11:1417-23.

85. Savini G, Monaco F, Terregino C, Di Gennaro A, Bano L, Pinoni C, et al. Usutu virus in Italy: an emergence or a silent infection? Vet Microbiol. 2011;151:264-74.

86. Ben Hassine T, de Massis F, Calistri P, Savini G, BelHaj Mohamed B, Ranen A, et al. First detection of co-circulation of West Nile and Usutu viruses in equids in the south-west of Tunisia. Transbound Emerg Dis. 2014;61:385-9.

87. Cadar D, Becker N, Campos Rde M, Börstler J, Jöst H, Schmidt-Chanasit J. Usutu virus in bats, Germany, 2013. Emerg Infect Dis. 2014;20:1771-3.
88. Escribano-Romero E, Lupulovic D, Merino-Ramos T, Blazquez AB, Lazic G, Lazic $S$, et al. West Nile virus serosurveillance in pigs, wild boars, and roe deer in Serbia. Vet Microbiol. 2015;176:365-9.

89. Grottola A, Marcacci M, Tagliazucchi S, Gennari W, Di Gennaro A, Orsini A, et al. Usutu virus infections in humans: a retrospective analysis in the municipality of Modena, Italy. Clin Microbiol Infect. 2017;23:33-7.

90. Steinmetz HW, Bakonyi T, Weissenböck H, Hatt JM, Eulenberger U, Robert N, et al. Emergence and establishment of Usutu virus infection in wild and captive avian species in and around Zurich, Switzerland - genomic and pathologic comparison to other central European outbreaks. Vet Microbiol. 2011;148:207-12.

91. Vázquez A, Ruiz S, Herrero L, Moreno J, Molero F, Magallanes A, et al. West Nile and Usutu viruses in mosquitoes in Spain, 2008-2009. Am J Trop Med Hyg. 2011;85:178-81.

92. Saiz JC, Blázquez AB. Usutu virus: current knowledge and future perspectives. Virus Adapt Treat. 2017;9:27-40.

93. Bakonyi T, Erdelyi K, Ursu K, Ferenczi E, Csorgo T, Lussy H, et al. Emergence of Usutu virus in Hungary. J Clin Microbiol. 2007:45:3870-4.

94. Weissenbock H, Bakonyi T, Rossi G, Mani P, Nowotny N. Usutu virus, Italy 1996. Emerg Infect Dis. 2013;19:274-7.

95. Cavrini F, Della Pepa ME, Gaibani P, Pierro AM, Rossini G, Landini MP, et al. A rapid and specific real-time RT-PCR assay to identify Usutu virus in human plasma, serum and cerebrospinal fluid. J Clin Virol. 2011;50:221-3.

96. Santini M, Vilibic-Caviek T, Barsic B, Barbic I, Savic V, Stevanovic V, et al. First cases of human Usutu virus neuroinvasive infection in Croatia, AugustSeptember 2013. Clinical and laboratory features. J Neurovirol. 2015;21:92-7.

97. Howell PG. The isolation and identification of further antigenic types of African horse sickness virus. Onderstepoort J Vet Res. 1962;29:139-49.

98. Chalmers AW. African horse sickness. Equine Vet J. 1968;1:1-4.

99. Boinas F, Calistri P, Domingo M, Avilés MM, López BM, Sánchez BR, et al. Scientific review on African Horse Sickness. 2009. https://efsa.onlinelibrary. wiley.com/doi/epdf/10.2903/sp.efsa.2009.EN-4. Accessed 24 May 2018.

100. World Organization for Animal Health. OlE-Listed diseases. 2018. http:// www.oie.int/animal-health-in-the-world/oie-listed-diseases-2018/. Accessed 24 May 2018.

101. Mellor PS, Boorman J. The transmission and geographical spread of African horse sickness and bluetongue viruses. Ann Trop Med Parasitol. 1995;89:1-15.

102. Carpenter S, Mellor PS, Fall AG, Garros C, Venter GJ. African horse sickness virus: history, transmission, and current status. Ann Rev Entomol. 2017;62:343-58

103. Parker J, Armstrong RM, Abegunde A, Taylor WP. African horse sickness in northern Nigeria. Res Vet Sci. 1977;26:274-80.

104. Henderson WW. Annual Report of Veterinary Department, Vom. Lagos: Government Press; 1933.

105. Anonymous. Department Records, Federal Department of Veterinary Research, Vom; 1959.

106. Anonymous. Department Records, Federal Department of Veterinary Research, Vom; 1967.

107. Kemp GE, Humburg JM, Alhaji I. Isolation and identification of African horse sickness. Vet Rec. 1971;89:127.

108. Best JR, Abegunde A, Taylor WP. An outbreak of African horse sickness in Nigeria. Vet Rec. 1975;97:394

109. Kwanashie G, Abdullahi SU. African horse sickness in imported horses in Kaduna and Kano States of Nigeria. In: Walton TE, Osburn Bl, editors. Proceedings 2nd International Symposium on Bluetongue, African horse sickness and related Orbiviruses. 17-21 June 1991, Paris: CRC Press; 1992. p. 217-21.

110. Oladosu LA, Olaleye OD, Baba SS, Omilabu SA. Isolation and identification of African horse sickness virus during an outbreak in Lagos, Nigeria. Rev Sci Tech Off Int Epiz. 1993;12:873-7.

111. Kazeem MM, Rufai N, Ogunsan EA, Lombin LH, Enurah LU, Owolodun O. Clinicopathological features associated with the outbreak of African horse sickness in Lagos, Nigeria. J Equine Vet Sci. 2008;28:594-7.

112. Fasina F, Potgieter AC, Ibironke A, Bako B, Bwala D, Kumbish P. First report of an outbreak of African horse sickness virus serotype 2 in the northern hemisphere. J Equine Vet Sci. 2008;28:167-70.

113. Lazarus DD, Atuman SS, Mshelia WP, Fasina FO. A report of African horse sickness in a captive zebra. In: 47th Annual Congress of Nigerian Veterinary Medical Association (NVMA), Benue State, Nigeria. Abuja: NVMA; 2010. p. 71

114. Baba SS, Olaleye OD, Ayanbadejo OA. Haemagglutimation-inhibiting antibodies against African horse sickness virus in domestic animals in Nigeria. Vet Res. 1993;24:483-7. 
115. Adeyefa CA, Hamblin C. Continuing prevalence of African horse sickness in Nigeria. Revue Elev Méd Vét Pays Trop. 1995;48:31-3.

116. Ehizibolo DO, Nwokike EC, Wungak Y, Meseko CA. Detection of African horse sickness virus antibodies by ELISA in sera collected from unvaccinated horses in Kaduna metropolis, Nigeria. Rev Elev Med Vet Pays Trop. 2014;67:73-5.

117. Swanepoel R. Nairovirus infections. In: Porterfield JS, editor. Exotic viral infections. London: Chapman and Hall; 1995, p. 285-93.

118. Ergonul O. Crimean-Congo hemorrhagic fever virus: new outbreaks, new discoveries. Curr Opin Virol. 2012;2:215-20.

119. Swanepoel R. Crimean-Congo hemorrhagic fever. In: Beran GW, editor Handbook of Zoonoses, section B: Viral zoonoses. 2nd ed. New York: CRC Press; 1994. p. 149-61.

120. Whitehouse CA. Crimean-Congo hemorrhagic fever. Antivir Res. 2004;64:145-60.

121. Watts DM, Ksiazek TG, Linthicum KJ, Hoogstraal H. Crimean-Congo hemorrhagic fever. In: Monath TP, editor. The arboviruses: epidemiology and ecology. Boca Raton. Florida: CRC Press; 1988. p. 177-222.

122. Acha PN, Szyfres B. Zoonoses and communicable diseases common to man and animals. 2nd ed. Washington, DC: Pan American Health Organization; 1991. p. 320

123. Aker S, Akinci $H$, Kilicoglu $C$, Leblebicioglu $H$. The geographic distribution of cases of Crimean-Congo haemorrhagic fever: Kastamonu, Turkey. Ticks Tick Borne Dis. 2015;6:730-6.

124. Saijo M, Tang Q, Shimayi B, Han L, Zhang Y, Asiguma M, et al. Possible horizontal transmission of Crimean-Congo hemorrhagic fever virus from a mother to her child. Japanese J Infect Dis. 2004;57:55-7.

125. Ergonul O. Crimean-Congo haemorrhagic fever. Lancet Infect Dis. 2006;6:203-14.

126. Athar MN, Baqai HZ, Ahmad M, Khalid MA, Bashir N, Ahmad AM, et al. Short report: Crimean-Congo hemorrhagic fever outbreak in Rawalpindi, Pakistan. Am J Trop Med Hyg. 2003;69:284-7.

127. Garcia S, Chinikar S, Coudrier D, Billecocq A, Hooshmand B, Crance JM, et al. Evaluation of Crimean-Congo hemorrhagic fever virus recombinant antigen expressed by Semliki Forest suicide virus for $\operatorname{lgM}$ and $\lg \mathrm{G}$ antibody detection in human and animal sera collected in Iran. J Clin Virol. 2006;35:154-9.

128. Mariner JC, Morrill J, Ksiazek TG. Antibodies to hemorrhagic fever viruses in domestic livestock in Niger: Rift Valley fever and Crimean-Congo hemorrhagic fever. Am J Trop Med Hyg. 1995;53:217-21.

129. Nabeth $P$, Cheikh DO, Lo B, Faye O, Vall IO, Niang M, et al. Crimean-Congo hemorrhagic fever, Mauritania. Emerg Infect Dis. 2004;10:2143-9.

130. Nabeth $P$, Thior M, Faye O, Simon F. Human Crimean-Congo hemorrhagic fever, Senegal. Emerg Infect Dis. 2004;10:1881-2.

131. Saluzzo JF, Digoutte JP, Cornet M, Baudon D, Roux J, Robert V. Isolation of Crimean-Congo haemorrhagic fever and Rift Valley fever viruses in Upper Volta. Lancet. 1984;1(8387):1179.

132. Zivcec M, Maïga O, Kelly A, Feldmann F, Sogoba N, Schwan TG, et al. Unique strain of Crimean-Congo hemorrhagic fever virus, Mali. Emerg Infect Dis. 2014;20:911-3.

133. Causey OR, Kemp GE, Madbouly MH, Lee VH. Congo virus from domestic livestock, African hedgehog and arthropods in Nigeria. Amer J Trop Med Hyg. 1970;19:846-50.

134. David-West TS, Cooke AR, David-West AS. Seroepidemiology of Congo virus (related to the virus of Crimean haemorrhagic fever) in Nigeria. Bull World Health Organ. 1974;51:543-6.

135. Umoh JU, Ezeokoli CD, Ogwu D. Prevalence of antibodies to Crimeanhaemorrhagic fever Congo virus in cattle in northern Nigeria. Int J Zoon. 1983;10:151-4

136. Tomori O, Fabiyi A, Sorungbe A, Smith A, McCormick JB. Viral haemorrhagic fever antibodies in Nigerian populations. Amer J Trop Med Hyg. 1988;38:407-10.

137. Bukbuk DN, Duwall SD, Lewandoski K, Bosworth A, Baba SS, Varghese A, et al. Serological and virological evidence of Crimean-Congo haemorrhagic fever circulation in the human population of Borno State, northeastern Nigeria. PLoS Negl Trop Dis. 2016;10:e0005126.

138. Tulman ER, Delhon GA, Ku BK, Rock DL. African swine fever virus. Curr Top Microbiol Immunol. 2009:328:43-87.

139. Dixon LK, Costa JV, Escribano JM, Rock DL, Venuella E, Wilkinson PJ. Family Asfarviridae. Virus taxonomy: Seventh report of the international committee on taxonomy of viruses. London: Academic Press; 2000. p. 159-65.

140. Majiyagbe KA, Shamaki D, Luther NJ, Udeani TKC. African swine fever epidemics: the Nigeria experience (1997-2004). Vom J Vet Sci. 2004;1:138-53.

141. Penrith ML, Vosloo W. Review of African swine fever: transmission, spread and control. J S Afr Vet Assoc. 2009;80:58-62.
142. Etter EMC, Seck I, Grosbois V, Jori F, Blanco E, Vial L, et al. Seroprevalence of African swine fever in Senegal, 2006. Emerg Infect Dis. 2011;17:49-54.

143. El-Hicheri K. Emergency assistance on control and eradication of an outbreak of African swine fever in Western Nigeria. Report of the FAO Consultancy Mission to Nigeria. TCP/NIR/7822(E). Rome: FAO; 1998. http:// www.fao.org/tempref/FI/CDrom/aquaculture/a0845t/volume2/docrep/field/. !52367! 386223.htm. Accessed 25 May 2018.

144. Odemuyiwa SO, Adebayo IA, Ammerlaan W, Ajuwape ATP, Alaka OO, Oyedele Ol, et al. An outbreak of African swine fever in Nigeria: isolation and molecular characterization of the VP72 gene of a first isolate from West Africa. Virus Genes. 2000;139:139-42.

145. Babalobi OO, Ayoade GO, Olugasa BO, Oluwayelu DO, Oyedele O. Differential diagnosis of a swine epizootic of unknown etiology in Ibadan, Oyo State, Nigeria. Israel J Vet Med. 2003;58:86-9.

146. Babalobi OO, Olugasa BO, Oluwayelu DO, ljagbone IF, Ayoade GO, Agbede SA. Analysis and evaluation of mortality losses of the 2001 African swine fever outbreak, Ibadan, Nigeria. Trop Anim Hlth Prod. 2007;39:533-42

147. Luther NJ, Majiyagbe KA, Nwosuh Cl, Shamaki D. The epizootiology, prevalence and economic aspects of African swine fever in parts of Middle Belt central states of Nigeria. Trop Vet. 2007;25:96-100.

148. Owolodun OA, Yakubu B, Antiabong JF, Adefalujo OK, Ogedengbe ME, Obisakin ET, et al. Molecular assessment of African swine fever in NorthCentral Nigeria. Bull Anim Prod HIth Afr. 2007;55:96-103.

149. Luther NJ, Majiyagbe KA, Shamaki D, Lombin LH, Antiabong JF, Bitrus Y, et al. Detection of African swine fever virus genomic DNA in a Nigerian red river hog (Potamochoerus porcus). Vet Rec. 2007;160:58-9.

150. Kemp GE, Lee VH, Moore DL, Shope RE, Causey OR, Murphy FA. Kotonkan, a new rhabdovirus related to Mokola virus of the rabies serogroup. Am J Epidemiol. 1973:98:43-9.

151. Tomori O, Fagbami A, Kemp G. Kotonkan virus: experimental infection of White Fulani calves. Bull Epizoot Dis Afr. 1974;22:195-200.

152. Walker PJ, Klement E. Epidemiology and control of bovine ephemeral fever. Vet Res. 2015:46:124

153. Bevan LEW. Preliminary report on the so-called 'stiff-sickness' of cattle in Rhodesia. J Comp Pathol. 1907:20:104-13.

154. Burgess GW. Bovine ephemeral fever: a review. Vet Bull. 1971;41:887-95.

155. Walker PJ. Bovine ephemeral fever in Australia and the world. Curr Top Microbiol Immunol. 2005;292:57-80

156. Davis SS, Gibson DS, Clark R. The effect of bovine ephemeral fever on milk production. Aust Vet J. 1984;61:128.

157. Aziz-Boaron O, Klausner Z, Shenkar J, Gafni O, Gelman B, David D, et al. Circulation of bovine ephemeral fever in the Middle-East strong evidence for transmission by winds and animal transport. Vet Microbiol. 2012;158:300-7.

158. Murphy FA, Taylor WP, Mims CA, Whitfield SO. Bovine ephemeral fever virus in cell culture and mice. Arch Ges Virusforsch. 1972:38:234-49.

159. Kemp GE, Mann ED, Tomori O, Fabiyi A, O'Connor E. Isolation of bovine ephemeral fever virus in Nigeria. Vet Rec. 1973;93:107-8.

160. Tomori O, Fagbami AH, Fabiyi A. Serum antibodies to two rhabdoviruses (bovine ephemeral fever and Kotonkan) in calves on the University of Ibadan Agricultural Farm. Bull Anim Hlth Prod. 1976;23:39-41.

161. Weiss KE, Haig DA, Alexander RA. Wesselsbron virus, a virus not previously described, associated with abortion in domestic animals. Onderstepoort J Vet Res. 1956:27:183-95.

162. Kemp GE, Causey OR, Moore DL, O'Connor EH, Murphy FA. Viral isolates from livestock in northern Nigeria. Amer J Vet Res. 1973;34:707-10.

163. Fagbami AH. Susceptibility of West African dwarf sheep to the indigenous Wesselsbron virus. Br Vet J. 1980;136:57-62.

164. Fagbami $\mathrm{AH}$, Ojeh $\mathrm{C}$. Wesselsbron virus infection in the West African dwarf sheep. Effect of pre-infection flavivirus antibody on severity of disease. Vet Microbiol. 1981;6:287-93.

165. Tomori O, Monath TP, O'Connor HE, Lee HV, Cropp BC. Arbovirus infections among laboratory personnel in Ibadan, Nigeria. Am J Trop Med Hyg. 1981; 30:855-61.

166. Baba SS, Fagbami AH, Omilabu SA. Wesselsbron virus infection in West African Dwarf goats (Fouta Djallon): virological and immunological studies. Acta Virol. 1989:33:81-6.

167. Baba SS, Fagbami AH, Ojeh CK, Olaleye OD, Omilabu SA. Wesselsbron virus antibody in domestic animals in Nigeria: retrospective and prospective studies. New Microbiol. 1995;18:151-62. 
168. Hoffmann B, Scheuch M, Hoper D, Jungblut R, Holsteg M, Schirrmeier H, et al. Novel Orthobunyavirus in Cattle, Europe, 2011. Emerg Infect Dis. 2012;18: 469-72

169. Causey OR, Kemp GE, Causey CE, Lee VH. Isolations of Simbu-group viruses in Ibadan, Nigeria 1964-69, including the new types Sango, Shamonda, Sabo and Shuni. Annals Trop Med Parasitol. 1972;66:357-62.

170. Goller KV, Höper D, Schirrmeier H, Mettenleiter TC, Beer M Schmallenberg virus as possible ancestor of Shamonda virus. Emerg Infect Dis. 2012;18:1644-6.

171. Conraths F, Peters M, Beer M. Schmallenberg virus, a novel orthobunyavirus infection in ruminants in Europe: potential global impact and preventive measures. N Z Vet J. 2012;61:63-7.

172. Bradshaw B, Mooney J, Ross PJ, Furphy C, O'Donovan J, Sanchez C, et al. Schmallenberg virus cases identified in Ireland. Vet Rec. 2012;171:540-1.

173. Shaw AE, Mellor DJ, Purse BV, Shaw PE, McCorkell BF, Palmarini M. Transmission of Schmallenberg virus in a housed dairy herd in the UK. Vet Rec. 2013:173:609.

174. Beer M, Conraths FJ, van der Poel WH. Schmallenberg virus - a novel orthobunyavirus emerging in Europe. Epidemiol Infect. 2013;141:1-8.

175. van den Brom R, Luttikholt SJ, Lievaart-Peterson K, Peperkamp NH, Mars MH, van der Poel $\mathrm{WH}$, et al. Epizootic of ovine congenital malformations associated with Schmallenberg virus infection. Tijdschr Diergeneeskd. 2012; 137:106-11.

176. Varela M, Schnettler E, Caporale M, Murgia C, Barry G, McFarlane M, et al. Schmallenberg virus pathogenesis, tropism and interaction with the innate immune system of the host. PLoS Pathog. 2013;9:e1003133.

177. Linden A, Desmecht D, Volpe R, Wirtgen M, Gregoire F, Pirson J, et al. Epizootic spread of Schmallenberg virus among wild cervids, Belgium, Fall 2011. Emerg Infect Dis. 2012;18:2006-8.

178. Jack C, Anstaett O, Adams J, Noad R, Brownlie J, Mertens P. Evidence of seroconversion to SBV in camelids. Vet Rec. 2012;170:603.

179. De Regge N, Deblauwe I, De Deken R, Vantieghem P, Madder M, Geysen D, et al. Detection of Schmallenberg virus in different Culicoides spp. by realtime RT-PCR. Transbound Emerg Dis. 2012;59:471-5.

180. Rasmussen LD, Kristensen B, Kirkeby C, Rasmussen TB, Belsham GJ, Bodker R, et al. Culicoids as vectors of Schmallenberg virus. Emerg Infect Dis. 2012;18:1204-6.

181. Elbers ARW, Meiswinkel R, van Weezep E, van Oldruitenborgh-Oosterbaan MMS, Kooi EA. Schmallenberg virus in Culicoides spp. biting midges, the Netherlands, 2011. Emerg Infect Dis. 2013;19:106-9.

182. Larska M, Polak MP, Grochowska M, Lechowski L, Zwiazek JS, Zmudzinski JF. First report of Schmallenberg virus infection in cattle and midges in Poland. Transbound Emerg Dis. 2013;60:97-101.

183. Meiswinkel R, Baldet T, De Deken R, Takken W, Delecolle JC, Mellor PS. The 2006 outbreak of bluetongue in northern Europe - the entomological perspective. Prev Vet Med. 2008;87:55-63.

184. Vanbinst T, Vandenbussche F, Vandemeulebroucke E, De Leeuw I, Deblauwe I, De Deken G, et al. Bluetongue virus detection by real-time RT-PCR in Culicoides captured during the 2006 epizootic in Belgium and development of an internal control. Transbound Emerg Dis. 2009:56:170-7.

185. Leask R, Botha AM, Bath GF. Schmallenberg virus - Is it present in South Africa? J South Afr Vet Assoc. 2013;84:a535.

186. Blomstrom AL, Stenberg H, Scharin I, Figueiredo J, Nhambirre O, Abilio AP, et al. Serological screening suggests presence of Schmallenberg virus in cattle, sheep and goat in the Zambezia Province, Mozambique. Transbound Emerg Dis. 2014:61:289-92.

187. Mathew C, Klevar S, Elbers ARW, van der Poel WHM, Kirkland PD, Godfroid J, et al. Detection of serum neutralizing antibodies to Simbu sero-group viruses in cattle in Tanzania. BMC Vet Res. 2015;11:208.

188. Calisher CE. History, classification and taxonomy of viruses in the family Bunyaviridae. In: Elliot RM, editor. Bunyaviridae. New York: Plenum Press; 1996. p. 1-17.

189. Bishop DHL, Shope RE. Bunyaviridae. In: Fraenkel-Conrat H, Wagner RR, editors. Comprehensive virology, vol. 14. New York: Plenum Press; 1979. p. 1-156.

190. Huang CC, Huang TS, Deng MC, Jong MH, Lin SY. Natural infections of pigs with Akabane virus. Vet Microbiol. 2003;94:1-11.

191. Davies FG, Jessett DM. A study of the host range and distribution of antibody to Akabane virus (Genus Bunyavirus, family Bunyaviridae) in Kenya. J Hyg (Lond). 1985;95:191-6.

192. Al-Busaidy S, Hamblin C, Taylor WP. Neutralizing antibodies to Akabane virus in free-living wild animals in Africa. Trop Anim HIth Prod. 1987;19:197-202.
193. Kurogi H, Inaba Y, Goto Y, Miura Y, Takahashi A. Serologic evidence for etiologic role of Akabane virus in epizootic abortion-arthrogryposishydranencephaly in cattle in Japan, 1972-1974. Arch Virol. 1975;47:71-83.

194. Metselaar D, Robin Y. Akabane virus isolated in Kenya. Vet Rec. 1976;99:86.

195. Mohamed ME, Mellor PS, Taylor WP. Akabane virus: serological survey of antibodies in livestock in the Sudan. Rev Elev Med Vet Pays Trop. 1996;49:285-8.

196. Elhassan AM, Mansour MEA, Shamon AAA, El Hussein AM. A serological survey of Akabane virus infection in cattle in Sudan. ISRN Vet Sci. 2014; 2014:123904.

197. Theodoridis A, Nevill EM, Els HJ, Boshoff ST. Viruses isolated from Culicoides midges in South Africa during unsuccessful attempts to isolate bovine ephemeral fever virus. Onderstepoort J Vet Res. 1979;46:191-8.

198. Zeller H, Bouloy M. Infections by viruses of the families Bunyaviridae and Filoviridae. Rev Sci Tech. 2000;19:79-91.

199. Blackburn NK, Searle I, Phelps BJ. Viruses isolated from Culicoides (Diptera: Ceratopogonidae) caught at the veterinary research farm, Mazowe, Zimbabwe. J Entomol Soc South Afr. 1985;48:331-6.

200. Ate IU, Allam L. Multiple congenital skeletal malformations in a lamb associated with dystocia in a Yankasa ewe. Nig Vet J. 2002;23:61-3.

201. Bukar MM, Waziri M, Ibrahim UI. Dystocia due to arthrogryposis and associated with a mummified twin in a crossed (Yankassa/Uda) ewe: a case report. Trop Vet. 2006;24:85-8.

\section{Ready to submit your research? Choose BMC and benefit from:}

- fast, convenient online submission

- thorough peer review by experienced researchers in your field

- rapid publication on acceptance

- support for research data, including large and complex data types

- gold Open Access which fosters wider collaboration and increased citations

- maximum visibility for your research: over $100 \mathrm{M}$ website views per year

At BMC, research is always in progress.

Learn more biomedcentral.com/submissions 